\title{
The impacts of Covid-19 on the students learning behavior
}

\author{
Ninik Suryatiningsih, Barotun Mabaroh, Sugeng Pradikto \\ English Education Department Study Program, Faculty of Pedagogy and Psychology, PGRI \\ Wiranegara University Pasuruan, East Java, Indonesia \\ ninik.suryatiningsih@gmail.com, barotunmabaroh@yahoo.com
}

\begin{abstract}
The pandemic's unpredictable period affected students' adjustment to daily life, financial costs, burdens, and "new" learning. The researchers believe that those aspects relate each other. Indeed, this research is not simply to know the students' problem behavior in the "new" learning class, but it also discover things to reduce risks for academic failure. In addition, the researchers felt urgent to discuss about the impact of COVID-19 towards the university students' learning behavior in order to evaluate some aspects need to encounter by lecturers for successful "new" learning. This was designed as a descriptive quantitative research. The data were taken by using the Problem Behavior Questionnaire (PBQ) distributed to the students through Google Form. The subjects consisted of 21 students of Economic Education Department Study Program, Faculty of Pedagogy and Psychology, PGRI Wiranegara University. From the questionnaire, the researchers could understand how COVID19 give impacts on the students in a relation to their sensory, control, and setting/environment. Furthermore, the researchers also evaluated how the students behave towards those counted parts. This research resulted the learning process at pandemic Covid-19 got harder than in the normal situation and it caused many problems in students' learning behavior. Hence, in order to make the students keep motivated, the lecturers need to give attention and motivation to decrease a negative behavior which also effect to their learning achievement.
\end{abstract}

Keywords: Behavior, Learning, The Impact of COVID 19, University Students.

\section{Introduction}

Since March 2020, there are many researches discussing about the impacts of the Corona Virus disease 2019 (COVID-19) to educational, economic, medical aspects, etc. Surely, the pandemic's unpredictable period, whether in short, medium, or long-term impact, affected students and pushed them to adjust into "new" daily life, financial costs, burdens, and learning classes. This research is valuable since this studied the special case of "new" learning during this pandemic period. To be known, the "new" learning has been conducted for almost two semesters. Many research reported students mostly get bored and show reluctant behavior in joining online class meeting. Therefore, the researchers were eager to study it more thorougly in the context of PGRI Wiranegara University.

The researchers understand that learning behavior is the way people learn and comprehend through a process. According to [1], the teacher/ student, material, and learning environment are three dimensions of learning which create learning behavior. Then, patterns in the learning behavior can be 
grouped into three categories; 1) behaviorism, 2) cognitivism, and 3) constructivism learning theories. Among these three categories, the researchers focus on Behaviorism learning theories which had been formulated in the late of 1800 's. Basically, its general goal was to derive elementary laws of learning and behavior that explain more complex relations [2].

According to [3], behaviorism is a primarily concern which observe and measure aspects of human behavior emphasizing the changes of behavior with stimulus-response collaboration. [4] states the characteristics of behaviorism are focus on environmental influences, the parts of the whole, psychomotor reactions, the causes of experience, the forming habits, and learning outcomes as the priority. Furthermore, [5] add that students' behavior through the class interaction reflected the students' temperament and inherited personality, the history of their experiences, and the particular nature of each situation. Based on this understanding, the researchers would discover how Covid-19 influenced some aspects on the students which need to encounter by any educators, especially university lecturers, to make a successful "new" learning.

In order to understand the students' behavior, the researchers had looked up the contracts, consequences, reinforcement, and extinction of English for Economics Course since those four are elements that can be used to foster the students' behavior [6]. According to [6], contracts mean that will help students to focus on their behavior change or the guidance for teaching at school and the parents' monitoring at home. Meanwhile, consequences related to action after a behavior. It can be positive or negative, expected or unexpected, immediate or long term, extrinsic or intrinsic so on. Next, reinforcement should be given to the students whether the consequences occur wih the positive or negative behavior. Last, extinction is related to the reinforced stimulus.

[7] identified poor behavior and good behavior from academic and social community perspective. Harassment or name-calling and disruptive behavior such as whispering during classroom activities are example of poor behavior. Meanwhile, on another side, good habits in studying, reasoning, interacting with politeness, and taking some intellectual challenges belong to the students' good behavior. Unfortunately, during the pandemic COVID 19, [8] found the students' psychological problems on online learning. They confirmed that students got bored on online learning, felt anxious about their parents income, and exprienced mood swing toward assignment and task. [8] suggested the need for severe efforts in assisting the psychological well-being of students through the involvement of counselors and psychologists, or at least reducing the assignment and task load.

The researchers adapted Lewis' et al Problem Behavior Questionnaire (PBQ) for collecting data. It was because [9] had designed the PBQ as an instrument to assess the students' behavior problem in a general education setting. [10] supports by using the problem behavior questionnaire teachers could encounter the different reasons of the students' behavior problems in the classroom. Francis can discover various reasons including their lack attention from their parents, uninterested in learning, hyperactivity, over pampering by their parents, lack of professional help, loss of a loved one, laziness, fear of being rejected and being a 'symbol' of a special student. From 15 statements of Lewis' et al Problem Behavior Questionnaire (PBQ), the researchers here adapted 13 items regarded to the English for Economics Course context.

[11] reported that more than 530.000 schools have closed amid the COVID-19 and affected 68 million students from all levels in Indonesia. The learning process must continue through new learning habits. However, the successful learning nowadays cannot be claimed only based on the assignment/ task achievement but it must also pay attention to the students behavior toward the course. As lecturers, it is a must to make students encouraged because they are the most affected during this pandemic. By reviewing all of these research findings, the researchers were excited to examine the impact of Covid- 
19 on students' behavior in joining English for Economics Course at PGRI Wiranegara University, Pasuruan.

\section{Research Method}

The study was designed as a descriptive quantitative research. According to [12], a descriptive research is used for describing variables, symptoms, and or any condition; but not for examining hypotheses. [13] adds a descriptive research has seven forms; 1) survey, 2) case study, 3) comparative study, 4) time and movement study, 5) behavioral study, 6) quantitative analysis, and 7) operational study. Among these kinds of descriptive research, the present research was quantitative analysis because the researchers purposed to understand numerical data which relate and represent the students' problem behavior during online learning in this pandemic.

The present research was conducted at the Economics Department Study Program, Faculty Pedagogy, and Psychology of PGRI Wiranegara University, Pasuruan, East Java, Indonesia. It took 21 students of the third semester as the research subject. The students were chosen because they were joining in English for Economics Course in academic year 2020/2021 which was actually the course with special purpose, or not a compulsory course. The researchers collected the data using the Problem Behavior Questionnaire (PBQ) distributed to the students through Google Form.

The questionnaire was adapted from Problem Behavior Questionnaire (PBQ) as formulated by [9], Virginia Department of Education, Division of Special Education and Student Services with guidelines for conducting functional behavior assessment and developing positive behavior intervention and supports/strategies. About the PBQ validity, Bhar et al (2008) noted that Lewis' et al PBQ has a quite good discriminant validity since it could show diagnostic groups measures of dysfunctional beliefs and characteristics.

Lewis's et al PBQ consisted of 15 statements. But, the researchers here adapted it into 13 (thirteen) statements in accordance with the subject context. All 13 (thirteen) statements represented for students' problem behavior during COVID 19 pandemic. All 13 (thirteen) statements relate to their sensory, control, and setting/environment. Statement number one was "The problem behavior during Covid-19 occur and persist me a request to perform a task". Next statement was "Covid-19 has greatly affected me following the rules of learning". The third statement was "I tend to let my peers alone when they have a conflict in doing classroom activities during Covid-19".

Statement four was "I can verbally respond to friend's problem behavior". Statement five was "During Covid-19, the problem behavior occurs mostly from a conflict outside of the classroom". Next was "The problem behavior influenced me during I am working with other students". The seventh statement was "The problem behavior influenced me to my specific peers". The following was "The problem behavior mostly continues to occur throughout the day". The ninth was "The problem behavior occurs during specific academic activities". Next was "The problem behavior ended when I stop interacting with my peers". Statement number eleven was "When the problem behavior occurs to the students, the lecturer gives specific instruction to ask me to back on the learning activity or task". The following was "The problem behavior ease to stop by making some request to end the academic activity". Last was "The problem behavior mostly occurs following unscheduled events or disruption in class routines".

Interview to some students was also done in order to support the information gathered through the questionnaire. The primary data was in the form of the students' responses to the statements on Google Form. The researchers analyzed the data by describing in details and responding it with relevant theories. 


\section{Result and Discussion}

Since March 2020, there are many researches discussing about the impacts of the Corona Virus The adapted Problem Behavior Questionnaire (PBQ) in this research consisted 13 (thirteen) statements related to the students' sensory, control, and setting/environment. Then researchers listed never, $10 \%$, $25 \%, 50 \%, 75 \%, 90 \%$, and always to represent accountable moment or preference for every statement in PBQ. As 0\% was represented by never, 100\% was represented by always. $10 \%$ represented for rarely, $25 \%$ for seldom, and $50 \%$ for sometimes. Often was represented by $75 \%$. Last, $90 \%$ meant normally/generally. The result of distributing the PBQ is shown by table

Table 1. Result from Questionnaire by Google Form

\begin{tabular}{|c|c|c|c|c|c|c|c|}
\hline Statement & Never & $10 \%$ & $25 \%$ & $\mathbf{5 0 \%}$ & $75 \%$ & $90 \%$ & Always \\
\hline 1. The problem behavior & 3 & 0 & 1 & 5 & 6 & 0 & 3 \\
\hline $\begin{array}{l}\text { during Covid-19 occur and } \\
\text { persist me a request to } \\
\text { perform a task }\end{array}$ & $16,7 \%$ & & $5,5 \%$ & $27,8 \%$ & 33,3 & & $16,7 \%$ \\
\hline 2. Covid-19 has greatly & 0 & 0 & 1 & 4 & 6 & 3 & 4 \\
\hline $\begin{array}{l}\text { affected me following the } \\
\text { rules of learning }\end{array}$ & & & $5,5 \%$ & $22,2 \%$ & $33,3 \%$ & $16,7 \%$ & $22,2 \%$ \\
\hline 3. I tend to let my peers & 1 & 0 & 2 & 9 & 5 & 1 & 0 \\
\hline $\begin{array}{l}\text { alone when they have a } \\
\text { conflict in doing classroom } \\
\text { activities during Covid-19 }\end{array}$ & $5,5 \%$ & & $11,1 \%$ & $50 \%$ & $27,8 \%$ & $5,5 \%$ & \\
\hline 4. I can verbally respond to & 0 & 2 & 1 & 6 & 6 & 0 & 3 \\
\hline friend's problem behavior & & $11,1 \%$ & $5,5 \%$ & $33,3 \%$ & $33,3 \%$ & & $16,7 \%$ \\
\hline 5. During Covid-19, the & & 2 & 3 & 8 & 4 & 0 & 4 \\
\hline $\begin{array}{l}\text { problem behavior occurs } \\
\text { mostly from a conflict } \\
\text { outside of the classroom }\end{array}$ & 0 & $11,15 \%$ & $16,7 \%$ & $44,4 \%$ & $22,2 \%$ & & $22,2 \%$ \\
\hline 6. The problem behavior & 0 & 1 & 2 & 3 & 9 & 1 & 2 \\
\hline $\begin{array}{l}\text { influenced me during I am } \\
\text { working with other } \\
\text { students }\end{array}$ & & $5,5 \%$ & $11,1 \%$ & $16,7 \%$ & $50 \%$ & $5,5 \%$ & $11,1 \%$ \\
\hline 7. The problem behavior & 0 & 0 & 6 & 3 & 5 & 1 & 3 \\
\hline $\begin{array}{l}\text { influenced me to my } \\
\text { specific peers }\end{array}$ & & & $33,3 \%$ & $16,7 \%$ & $27,8 \%$ & $5,5 \%$ & $16,7 \%$ \\
\hline 8. The problem behavior & 1 & 0 & 4 & 5 & 3 & 1 & 6 \\
\hline $\begin{array}{l}\text { mostly continues to occur } \\
\text { throughout the day }\end{array}$ & $5,5 \%$ & & $22,2 \%$ & $27,8 \%$ & 16,7 & $5,5 \%$ & $33,3 \%$ \\
\hline 9. The problem behavior & 4 & 2 & 7 & 2 & 0 & 1 & 1 \\
\hline $\begin{array}{l}\text { occurs during specific } \\
\text { academic activities }\end{array}$ & $22,2 \%$ & $11,1 \%$ & $33,3 \%$ & $11,1 \%$ & & $5,5 \%$ & $5,5 \%$ \\
\hline 10. The problem behavior & 1 & 3 & 1 & 4 & 3 & 4 & 2 \\
\hline $\begin{array}{l}\text { ended when I stop } \\
\text { interacting with my peers }\end{array}$ & $5,5 \%$ & $16,7 \%$ & $5,5 \%$ & $22,2 \%$ & $16,7 \%$ & $22,2 \%$ & $11,1 \%$ \\
\hline $\begin{array}{l}\text { 11. When the problem } \\
\text { behavior occurs to the }\end{array}$ & 0 & 0 & $\begin{array}{r}1 \\
5,5 \%\end{array}$ & $\begin{array}{r}3 \\
16,7 \%\end{array}$ & $\begin{array}{r}7 \\
38,8 \%\end{array}$ & $\begin{array}{r}5 \\
27,7 \%\end{array}$ & $\begin{array}{r}2 \\
11,1 \%\end{array}$ \\
\hline
\end{tabular}
students, the lecturer gives specific instruction to ask me back to focus on the learning activity or task 12. The problem behavior ease to stop by making

$\begin{array}{rrrlrrr}2 & 4 & 5 & 0 & 3 & 2 & 2 \\ 11,1 \% & 22,2 \% & 27,8 \% & & 16,7 \% & 11,1 \% & 11,1 \%\end{array}$




$\begin{aligned} & \text { some request to end the } \\ & \text { academic activity }\end{aligned}$
$\begin{aligned} & \text { 13. The problem behavior } \\ & \text { mostly occurs } \\ & \text { following unscheduled }\end{aligned}$
$\begin{aligned} & \text { events or disruption in } \\ & \text { class routines }\end{aligned}$

For statement number one, the data showed three students $(16,7 \%)$ did not think that the lecturer persist them to perform a task during Covid-19 more than in normal condition. One student $(5,5 \%)$ chose seldom did the lecturer persist performing a task during Covid-19. Five students $(27,8 \%)$ thought sometimes the lecturer persist them more to perform a task during Covid-19. Six students $(33,3 \%)$ claimed performing a task during Covid-19 affected to their problem behavior. Moreover, three students felt $(16,7 \%)$ it was always that their problem behavior occur along with a request to perform a task from the lecturer. In conclusion, most of the students confirmed that the lecturer persist them to perform many tasks during Covid-19 and it gave them problems on their learning behavior.

The students' responses toward statement number two were various too. Four students $(22,2 \%)$ thought online learning situation during covid 19 motivate them to follow all rules of learning. It maybe because they would miss any part/ discussion if they did not obey the rules well. Generally, three students $(16,7 \%)$ also agree they must follow the rules of learning. Six students $(33 \%)$ often follow the rules of learning but they might ever ignore it. Meanwhile, four students $(22,2 \%)$ claimed they follow the rules of learning just sometimes, whenever they want to. Last, it was only one student $(5,5 \%)$ admitted seldom to follow the rules of learning. So, the researcher could understand that most of students tended to follow the rules of learning with several reasons although 5 of them preferred to ignore.

Eighteen students responded the third statement on PBQ. None of them tended to let their peers alone when they have a conflict in doing classroom activities. One student $(5,5 \%)$ stated he/she normally let his/her peers alone when they have a conflict in doing classroom activities during Covid-19. Five students $(27,8 \%)$ claimed they were often more individualistic by let their peers alone when they have a conflict in doing classroom activities during Covid-19. Nine students (50\%) sometimes gave help but some other times ignored peers alone when they have a conflict in doing classroom activities. Two students $(11,1 \%)$ seldom let their peers alone when they have a conflict in doing classroom activities. And, it was only one student $(5,5 \%)$ who would always give a help for their peers when they have a conflict in doing classroom activities during Covid-19. Based on this fact, it can be evaluated that the preference to let the peers alone when they have a conflict in doing classroom activities during Covid19 was high. In contrast, minority of students still paid and gave help for their peers alone when they have a conflict in doing classroom activities during Covid-19.

The researcher could get data that it was sometimes six students $(33,3 \%)$ can verbally respond to friend's problem behavior during Covid-19. The other six students claimed often respond to friend's problem behavior verbally. Next, three students $(16,7 \%)$ stated they always respond to friend's problem behavior verbally. One student $(5,5 \%)$ admitted seldom, moreover two students $(11,1 \%)$ rarely respond to friend's problem behavior. Responding to friend's problem behavior verbally during Covid-19 reflects the opposite intention of the third statement responses of PBQ. Giving a help when the peers have a conflict in doing classroom activities was harder for the students than responding verbally to friend's problem behavior with comments or suggestion at online class during Covid-19.

During Covid-19, the problem behavior for four students $(22,2 \%)$ occured mostly from a conflict outside of the classroom. It was supported by the other four students $(22,2 \%)$ who also claimed the 
problem behavior occurs often from a conflict outside of the classroom. Eight students $(44,4 \%)$ thought sometimes the problem occurs from a conflict within the classroom, but sometimes it was from outside of the classroom. Seldom, a conflict within the classroom became the students' problem behavior for three students $(16,7 \%)$. Even, two students $(11,1 \%)$ felt that the problem behavior occurs from a conflict outside of the classroom rarely. Total responses for this fifth statement were twenty. And from this result, it can be known that it was only five students argued that their problem behavior occur from a conflict within the classroom while most of students found it from a conflict outside of the classroom.

Statement number six discovered that nine students $(50 \%)$ often got influenced by the problem behavior during working with other students in the online class. Two students $(11,1 \%)$ felt always annoyed by the problem behavior during the class. One student $(55 \%)$ was normally influenced by it. However, three students $(16,7 \%)$ sometimes felt influenced, but sometimes not influenced, by the problem behavior during working with other students. One student $(5,5 \%)$ rarely felt that the problem behavior influenced him during working with other students, and two students $(11,1 \%)$ seldom felt it. This could show that the problem behavior annoyed most of students in online class during Covid-19.

Nine students responded "The problem behavior influenced me to my specific peers" with always $16,7 \%$ (from 3 students), generally 5,5\% (from 1 student), and often $27,8 \%$ (from 5 students). Three students $(16,7 \%)$ stated sometime they felt that the problem behavior gave influence to their specific peers. Six students $(33,3 \%)$ even argued that it influenced their specific peers. Next, the students responded the eighth statement variously. It was only one student $(5,5 \%)$ claimed that the problem behavior never continues to occur throughout the day. Four students $(22,2 \%)$ stated it seldom occured throughout the day. Yet, fifteen students confirmed that the problem behavior mostly continues to occur throughout the day; with 5 responses in sometimes $(27,8 \%), 3$ responses in often $(16,7), 1$ response in generally $(5,5 \%)$, and 6 responses in always $(33,3 \%)$.

Statement number nine was responded with always by one student $(5,5 \%)$. Generally, one student $(5,5 \%)$ also saw the problem behavior occurs during specific academic activities. Sometimes, two students $(11,1 \%)$ felt it occurs during specific academic activities. But seven students $(33,3 \%)$ stated the problem behavior seldom occurs during specific academic activities. Furthermore, two students $(11,1 \%)$ chose rarely while the rest four students $(22,2 \%)$ chose it never occurs during specific academic activities. This means that the students might experience the problem behavior without any intention to specific academic activities or specific courses.

Two students $(11,1 \%)$ claimed the problem behavior can be ended when they stop interacting with peers during online learning. It is supported by four students $(22,2 \%)$ who stated they need to stop interacting with peers in order to end the problem behavior. Three students $(16,7 \%)$ admitted often and the other four students $(22,2 \%)$ felt sometimes the problem behavior ended if they stop interracting with peers. However, it was okkay for 5 students to interreact with their peers since they understood the problem behavior did not always come from their peers at online class. Therefore, 1 student $(5,5 \%)$ had choosen seldom and three students $(16,7 \%)$ chose rarely. Moreover, one student $(5,5 \%)$ never saw peers could provoke the problem behavior or, in other words, he was able to control when the problem behavior should be ended by himself not by stop interracting.

Most of students agreed that when the problem behavior occurs to the students, the lecturer gives specific instruction to focus back on the learning activity or task. It was $11,1 \%$ ( 2 students) claimed it always, $27,7 \%$ (5 students) generally, 38,8\% (7 students) often, and 16,7\% (3 students) sometimes. Only one student $(5,5 \%)$ asserted that the lecturer seldom gave specific instruction to to focus back on the the learning activity or task when the problem behavior occur to the students. This proved that the 
lecturer as the class manager could handle if the problem behavior happened during the class. The lecturer was also able to keep students focused on the learning activity or task.

Making some request to end the academic activity did not absolutely stop the problem behavior easily. This was proven by the students response with never in $11,1 \%$ ( 2 students), rarely in $22,2 \%$ (4 students), and seldom in $27,8 \%$ (5 students). However, ending the academic activity woud always stop the problem behavior easily for two students $(11,1 \%)$. In addition, three students $(16,7 \%)$ admitted it was often and the rest two students $(11,1 \%)$ claimed it was generally.

The last statement in PBQ was "The problem behavior mostly occurs following unscheduled events or disruption in class routines". Three students $(16,7 \%)$ asserted it always occurs following unscheduled events or disruption in class routines. Moreover, eight students $(44,4 \%)$ claimed it generally. Seven students $(33,3 \%)$ preferred to choose sometimes while the other three students $(16,7 \%)$ felt it seldom occurs following unscheduled events or disruption in class routines. This data is meaning that it is better to design distinct course criteria, schedule, and activities in a syllabus so the students could prepare better for the class in today's pandemic phase. The lecture's unscheduled events or disruption in class routines would be able to increase the students' problem behavior since they must adjust to many and more complex things.

Regarding the elaborated result, the researchers reviewed [14] evaluation since the researchers revealed that the students' problem behavior in learning during this pandemic can occur because of the students' less motivation and gaps between the students and the lecturer. Barton-Arwood et al see the problem behavior Questionnaire (PBQ) can be the guidance for the lecturer to enhance students' motivation and qualify their learning behavior. Indeed, it is not deniable that learning today become more challenging for the students and even the lecturer. Learning online is more recommended with some requisites today and the lecturer must be ready with all kinds of students' learning behavior.

[15] recommends giving positive feedback to the students since it is advantageous in increasing students' motivation, confidence, self-efficacy and academic skills. Next, according to [16], to approach and reduce student problem behavior can also be done by empowering them to "school", motivating them to be more positive, and also managing for co-joint learning practices. The lecturer may approach the students who are lack of confidence with positive reinforcement. Patiently listening to the students' needs, showing respect, and preserving their dignity could also encourage students for positive behavior.

Furthermore, [17] suggested four ways to solve behaviroal gaps between the students and the lecturer. First, the lecturer could find out the solution for the students without internet access. This is because the students behave ignoring the learning rules due to unaccessible internet on their area. One of the alternatives is by giving such a supplementary task to replace their absence from class. But, this did not mean that the students could join or not join the class perfunctorily. They must still confirm their connection problem to the lecturer, and hence the lecturer could find best solution indeed.

Second, the lecturer should deliver more effective and interactive online learning. Interraction with peers in groups through online discussion can increase the students' enthusiasm because they have similar feeling and struggle to pass. Related to cooperation with peers on online class, [18] noticed that it is not impossible conducting Cooperative Integrated Reading and Composition (CIRC) as one of cooperative learning model during pandemic in order to make online class effective although it require more efforts of the lecturer. Third, the lecturer must be ready with differentiated instruction. This option can reduce the students' problem behavior because changes will always occur during online learning. Fourth, the lecturer must always support and ensure the students everything will be okkay 
sooner. The lecturer can also pay attention by reminding them to follow the health procedures, stay happy, and keep motivated to learn well.

This research succeeded in discovering the impact of Covid 19 on the students learning behavior. According to [19], students' attitudes or behavior and lecturers emotional support classroom organization or in contrast make high risks for academic failure. Therefore, this research is useful since it and it could bridge the academic achievement by exploring the students' problem behavior and hence solve it precisely. [20] also suggested the government should provide extra investments to support the online learning system. If they dont take controls toward it, thus it would be very difficult both for lecturers or any educators and the students to focus on learning, balance and enhance their cognitive during the pandemic.

\section{Conclusion}

The present research shows that students faced many problem behaviors in learning during covid19. Those are reflected on the students' responses towards the Problem Behavior Questionnaire (PBQ). For statement number one, most of the students confirmed that the lecturer persist them to perform many tasks during Covid-19 and it could increase problems on their learning behavior. Then, the students also confirmed Covid-19 has greatly affected them in following the rules of learning. However, most of students tended to follow the rules of learning with several reasons although five of them preferred to ignore. The responses toward statement number three showed that majority of students preferred ignoring to helping their peers when they have a conflict in doing classroom activities during Covid-19.

Most of students could respond verbally to friend's problem behavior with comments or suggestion at online class during Covid-19. From the students' responses toward the fifth statement, most of students argued that their problem behavior come from a conflict outside of the classroom. Furthermore, the students' responses toward the sixth statement could show that the problem behavior annoyed most of students in online class during Covid-19. Some students felt their problem behavior influenced to specific peers, but some others didn't. Next, almost all students confirmed that the problem behavior mostly continues to occur throughout the day.

Furthermore, most students did not recognize that the problem behavior occurs at specific academic activities. Most of students also felt that the problem behavior can be ended easily when they stop interacting with peers on online learning. Giving specific instruction to focus back on the learning activity or task was the best lecturer's way responding the problem behavior during the class. Making some request to end the academic activity did not absolutely stop the problem behavior easily although some students preferred to it. Last, most of students confirmed that the problem behavior mostly occurs following unscheduled events or disruption in class routines. These all facts reflect the process of learning at pandemic Covid-19 is harder than the normal situation and it caused many problems on the students' learning behavior. Hence, in order to make the students keep motivated, the lecturer need to give attention and motivation to decrease a negative behavior which also effect to their learning achievement.

\section{References}

[1] Illeris, Knud 2004. The Three Dimensions of Learning. Malabar, Fla: Krieger Pub.

[2] Bryan D, Nakita J, Cameron, M \& Andrew S 2020. Behaviorism Theory and its relation to Instructional Design. NY: Routledge.

[3] Parkay, F.W. \& Hass, G 2000. Curriculum Planning (7th Ed.). Needham Heights, MA: Allyn \& Bacon.

[4] Muhajirah 2020. Basic of learning theory (behaviorism, cognitivism, constructivism, and 
humanism). IJAE (International Journal of Asian Education). Vol.1.No1.June 2020. eISSN:2722-8592.

[5] D. Joshi, V.A.Gokhale \& A.Acharya. 2012. Student's Response and Behavior in the Classroom Environment. International Journal for Cros-Discipline Subjects in Education (IJCDSE). Special Issue Volume 2 Issue 1, 2012.

[6] Zhou, M., \& Brown, D. (Eds.) 2017. Educational Learning Theories: 2nd Edition. Retrieved from https://oer.galileo.usg.edu/education-textbooks/2

[7] Bennet T, 2017 Creating a Culture: How School Leaders Can Optimise Behaviour UK Dep. Educ.

[8] Irawan A.W., Dwisona D, \& Mardi L 2020. Psychological Impact of Students on Online Learning During the Pandemic COVID-19. KONSELI, Journal Bimbingan dan Konseling, Vol 7, No 1, 2020. doi.org/10.24042/kons.v7i1.6389

[9] Lewis, Scott and Sugai 1994. Problem Behavior Questionnaire. https://www.doe.virginia.gov/support/student conduct/problem behavior questionn aire.pdf

[10] Francis C 2017. Teacher's Understanding about Behavioral Problems among Primary School Students.https://www.researchgate.net/publication/334273338 Teacher's Understandin g about Behavioral Problems among Primary School Students

[11] Bhardwaj R Yarrow N and Cali M, 2020 EdTech in Indonesia

[12] Arikunto, Suharsimi 2010. Prosedur Penelitian Suatu pendekatan Praktik. Jakarta : Rineka Cipta.

[13] Basuki, Sulistyo 2010. Metode Penelitian. Jakarta: Wedatama Widya Sastra.

[14] Barton-Arwood S, Wehby J, Gunter P, and Lane K 2003. Functional Behavior Assessment Rating Scales: Intrarater Reliability with Student with Emotional or Behavioral Disorders. Sage Publication, Inc. Vol.28.No.4 (August 2003), pp.386-400.

[15] Asryan Ani. Positive Feedback Improves Students' Psychological and Physical Learning Outcomes. Indonesian Journal of Educational Studies. Vol 22, No 2, 2019, p. 134-143 DOI: https://doi.org/10.26858/ijes.v22i2.11776

[16] M.A.Sorlie \& T.Ogden 2015. Preventing Problem Behavior in School through School-Wide Staff Empowerment : Intervention Outcomes. https://www.researchgate.net/deref/http\%3A\%2F\%2Fdx.doi.org\%2F10.22158\%2Fwjer.v2n2 p117

[17] D. Gupta \& N.N. Khairina 2020. COVID-19 and Learning Inequities in Indonesia: Four ways to Bridge the Gap. https://blogs.worldbank.org/eastasiapacific/covid-19-and-learninginequities-indonesia-four-ways-bridge-gap

[18] B. Mabaroh 2020. Penerapan Metode Cooperative Integrated Reading and Composition (CIRC) pada Kelas Daring di Masa Pandemi Covid-19. Berdaptasi Dengan Perubahan, Pembelajaran Bahasa dan Sastra di Masa Pandemi (Book Chapter, ed: Setyowati \& El Sulukiyyah). Sidoarjo: Delta Pijar Khatulistiwa.

[19] Blazar. D., and Kraft, M.A 2016. Teacher and Teaching Effect on Students' Attitudes and Behaviors. 2016. HHS Public Access,

[20] Gracia, E, \& Weiss, E 2020. COVID 19 and Student Performance, Equity and U.S. Education Policy: Lesson from Pre-pandemic Research to Inform Relief, Recovery, and Rebuilding. $\quad$ https://www.epi.org/publication/the-consequences-of-the-covid-19pandemic-for-education-performance-and-equity-in-the-united-states-what-can-welearn-from-pre-pandemic-research-to-inform-relief-recovery-and-rebuilding/ 